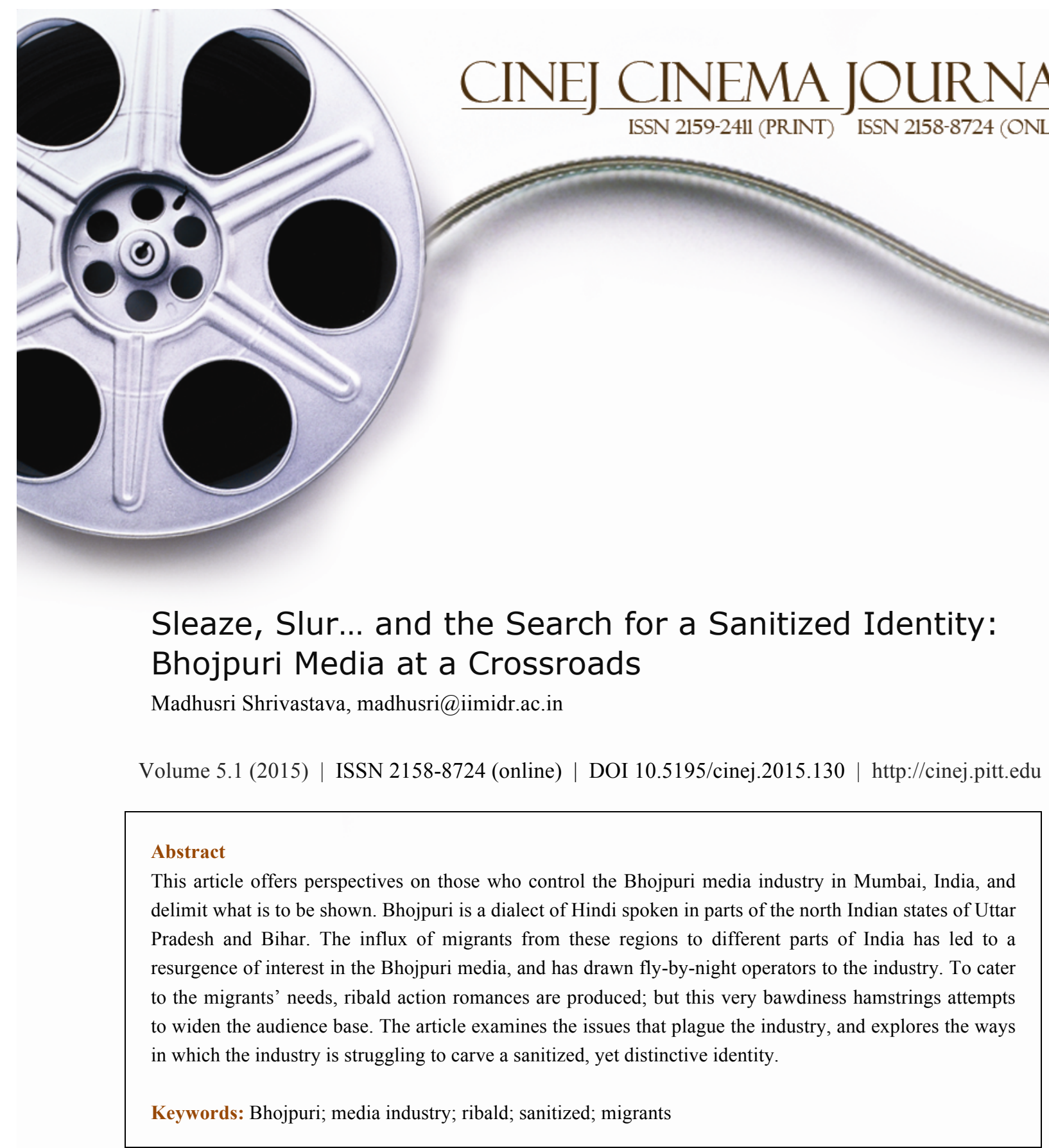

\title{
$(\mathrm{cc}) \mathrm{EY}$
}

New articles in this journal are licensed under a Creative Commons Attribution 4.0 United States License.

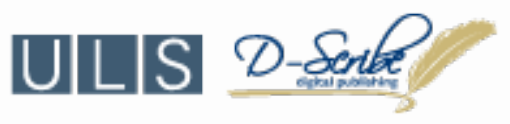

This journal is published by the University Library System of the University of Pittsburgh as part of its $\underline{D}$-Scribe Digital Publishing Program and is cosponsored by the University of Pittsburgh Press. 


\section{Sleaze, Slur... and the Search for a Sanitized Identity: Bhojpuri Media at a Crossroads \\ Madhusri Shrivastava}

This article seeks to explore the perspective of those who control the Bhojpuri culture industry, and delimit what is to be shown. It is part of a comprehensive research on the manner in which Bhojpuri media help north Indian migrants in Mumbai remain anchored to their traditions and values. Bhojpuri is a dialect of Hindi spoken in the north Indian states of Uttar Pradesh (UP) and Bihar. In the wake of the influx of migrants from these regions to different parts of India, there has been a phenomenal growth of interest in the Bhojpuri media, a fact that has drawn flyby-night operators to the industry. To cater to the needs of migrant labor, the industry produces action-romances replete with suggestive song and dance numbers.

The paper examines current trends in the Bhojpuri media industry and the pulls and pressures of market forces. It also seeks to understand the issues that plague the industry, and agenda setting, if any, by the producers. The research participants include journalists, successful film directors, the publisher of a film trade magazine, two thespians of Bhojpuri cinema, the producer of a local Bhojpuri cable TV channel in the north western suburbs of Mumbai, bit actors and singers.

The research is premised on the belief that human beings 'construct' meanings in the course of their engagement with the world they are interpreting. ${ }^{1}$ The basic assumption is that through an inductive process the researcher can arrive at a pattern of meaning that helps interpret the way others view the world. ${ }^{2}$ The methods used include in-depth interviews, group discussions, observation and content analysis. In natural settings, a combination of observation 
and interviews was employed, and thereafter, relationships and patterns were identified not just in the responses of the research participants, but also in cultural artefacts. This was done primarily to ensure a multi-perspectival approach in which insights gained from reception analysis and study of media texts were supplemented by those drawn from the arena of political economy ${ }^{3}$.

The research design selected was exploratory when open-ended questions were asked to elicit responses; a more descriptive design was employed to interpret attitudes and issues related to cultural identity.Participants included people directly or indirectly associated with the media. They were selected on the basis of my familiarity with them; snowball sampling was also used, and respondents were asked to suggest someone else who might be willing and appropriate for the study. The setting was always one in which the interviewee was in familiar surroundings and therefore, very comfortable. The interviews were unstructured so that the participants' perceptions could be understood and documented. At times, I was a nonparticipating observer: this was especially so when I was at the studios where the 'photo shoot' of a forthcoming Bhojpuri film was in progress. On other occasions, while watching a Bhojpuri music video or a television show with my research participants, I was closest to being a participant observer. Thus the degree of my 'participation' varied according to the opportunities afforded by the circumstances. The interviews were conducted in Hindi and were recorded, except in cases where the participants demurred.

The transcripts were read and reread to locate 'meaningful units'. The findings were reported in the form of a narrative that grouped observations under recurrent themes and areas of concern that emerged from the discussions. Inferences and identifiable patterns were 
reported as 'research based assertions' supported by analyses, relevant quotes from the interviews and interpretative comments, to present a comprehensive picture of the participants' outlook. Contents of the film trade magazine 'Bhojpuri City' were also analyzed to identify issues and concerns of relevance to media executives and producers of the Bhojpuri entertainment industry. Analysis of the commonalities that emerged in the participants' concerns helped in gaining further insights into their perspectives. The mode selected for expressing my understanding of the participants' views with regard to the Bhojpuri media, was chiefly descriptive. An attempt was made towards providing contextual completeness, i.e., detailed and accurate description of the research site as well as the subjects, to establish the interpretive validity of the inferences.

The search for research participants who could offer insights into the Bhojpuri media industry led me to film sets and green rooms, publishing houses, as well as studios. The most vocal among my research participants were the filmmakers Harry Fernandes and Anand Ghatraj, who offered the insiders' view of an industry drunk on its new found success. Kishan Khaderia, the publisher of a film trade magazine, and Parag Chapekar, a journalist and former anchor of a popular television show in Bhojpuri, provided objective analyses of the problems that beset the industry. My interactions with the celebrated actor Ravi Kishen, and Govind Khatri, villain of several Bhojpuri hits, buttressed the observations of the other respondents. From the collage of disparate voices and diverse views, gradually there emerged an eloquent picture of an industry riven by its inherent contradictions. What follows is my attempt to illumine that troubled terrain. 


\section{The Early Years}

The spectacular growth of the Bhojpuri media began in the last 30 years. In the phase extending from the early 1980 s up to 2005 , chiefly remakes were churned out by a film industry chary of experimentation and eager to ensure success at the box office. The first wave of Bhojpuri cinema (also known as Bhojwood in the popular press) had generous doses of the rustic culture: there were obvious borrowings from nautanki ${ }^{4}$, the folk theatre of UP and Bihar, and in keeping with the tradition of north Indian folk songs, the lyrics were replete with double entendres. Besides, popular actors such as Manoj Tiwari, Dinesh Lal Yadav and Pawan Singh had made their debut as folk singers, and it was therefore inevitable that sexually suggestive lyrics of the folk song genres should spill over into the films. Further, since the number of films was limited, (only about $3-4$ in a year) each film was eagerly awaited and hugely successful. As the number of releases increased, the quality suffered, and the monotony of the fare dished out adversely impacted the box office. The spate of remakes that set their sights on quick recoveries at the box office snuffed out quality. The earlier family dramas had gradually given way to action - romances that were replete with stunts, cleavage flashing girls and puns. Films were made under severe budget constraints. Because of the desperate need-to recover the money invested, distributors and financiers insisted on the mandatory titillation of item songs (seductive song and dance sequences), and never strayed too far from the tried and tested formula. 


\section{What Sells... and Why}

Harry Fernandes, one of the most successful directors in the industry, described how he had struck gold with Bhojpuryai Bhaiya (2005), a film that cost rupees 4.5 million to make and nineteen days to shoot. He took no chances, and made sure it contained action, drama, romance - saas-bahu (mother-in-law-daughter-in-law) conflict, a 'brother-sister' angle (i.e., the affectionate relationship between siblings)... the entire stock-in-trade that spelt success. There were ten songs; in fact, he said, the songs were interspersed with scenes. The film was a runaway hit, but Fernandes was emphatic that there was no guaranteed formula that spelt success at the box office. Bhed Chaal (herd instinct) was the only way to describe the trends in an industry in which rank amateurs jostled with each other in a feverish bid to make money. However, music, as Fernandes had discovered, held the key to success with the Bhojpuri audiences. Music, be it as an inalienable feature of the films, or as a means to gain entry into the charmed circle of A-listers, was the ticket to success in the Bhojpuri industry.

Fernandes revealed, "Films don't sell on the basis of heroines' glamour and acting; on the contrary, 'teams' sell'. That is, the team of a hero, a director and perhaps a heroine, and a music director, would fetch a larger sum from the financier. More than the individual star, it was a 'package' that sold. For instance, a combination of the star Ravi Kishen, a particular director, music director and a heroine would possibly fetch a price of rupees 2 to 2.5 million. Films that had star power would perhaps effortlessly get the expected returns. By themselves the heroines had no 'selling value'; in conjunction with a male superstar, they commanded a better price. 


\section{Twin Strands in Bhojpuri Cinema}

Unequivocally, the respondents maintained that the formula was purely market driven, as was the industry. According to Chapekar, the film journalist, two parallel strands were visible in Bhojpuri cinema: one was the kind of film that was screened in the multiplexes of UP and Bihar; the other was the kind that was made on a shoestring budget (often less than rupees 1.5 - 2 million), and was shown using projectors in ramshackle, run-down theatres or even in melas (village fairs). Kishen Khaderia, the publisher of the Bhojpuri film magazine Bhojpuri City, has had a long association with the production of films in the past, and has an insider's knowledge of the industry. He too declared that there were two kinds of films being made in Bhojpuri. The first category of films was purely entertaining and was chockfull of the features of Hindi cinema of the 1960s and 1970s. He said, "The story is of least concern... there is nautanki; rich girl meets poor boy... and the atrocities of rich men. "The narrative is punctuated with ten to fifteen songs. The music invariably has a touch of the rustic, and the folksy tunes remind the viewers of their home state. "The lyrics", Khaderia remarked, "are bad". There are several references to women's clothing odhani and chunri (long scarves used to cover the head and bosom), choli (blouse)... And each of these is imbued with double meanings. He went on to say that the patrons found such naach gaana (cheap songs and dances) immensely enjoyable. Women rarely went to the cinema theatres; the explicit lyrics, and the dances, did not meet with their approval. But there was a 'basic' audience of about 100,000 that watched any film in Bhojpuri; if the film was a hit, the number would go up to 150,000 . If it was a flop, the number would drop to 50,000 . 
The second category of films was women oriented: the kind of films that carried a message woven around some tradition or custom prevalent in Bihar: for instance, widow remarriage, or the practice of compelling widows to shave their heads. The story lines of such films were stronger; though they were not always in tune with contemporary issues. He described them as "good stories as per their community and society" (sic). Prompted by the very same desire to make 'good' films, Anand Ghatraj had decided to buck the trend. His directorial venture, the Bhojpuri film Kab Hoi Gawana Hamar (When Shall I Go to My Husband's Home) had won him the national award in 2005. But his film Pratha (custom) was about the travails of a nineteen year old widow oppressed by outmoded customs. Sitting in a poky little shed named Dream focus studio, supervising a photo shoot for his film, Ghatraj elaborated on how he was taking a huge risk. His purpose was to get the male audience of Pratha to go and discuss the film with their women-folk at home, and bring them back to the theatre. He went on to underscore one of the biggest concerns of Bhojpuri film directors: how to woo the women back to the theatres.

This was a recurrent complaint against Bhojpuri media: the grossness of depiction repelled women and the educated sections of the society. Moreover, the conservative ethos of the north Indian states was also responsible for the women staying away from cinema theatres. The men preferred to keep their womenfolk out of public spaces, away from the gaze of other men. Ravi Kishen, a veteran of several blockbuster hits, spoke of the need to 'break the mould' the audience was caught in. He cited the example of several 'clean' family dramas he had acted in: films like Bidaai (ritual of the bride's departure from the parental home to her in laws' house), Kanyadaan (ritual of giving away the bride) and Santaan (progeny) that had eschewed ribaldry and reintroduced 'meaningful themes' to Bhojpuri cinema. 
Nonetheless, no more than 5 to $10 \%$ of the Bhojpuri films belonged to this genre. Khaderia affirmed that they did very well at the box office, as did mythological films. In fact, certain devotional themes were guaranteed to set the cash registers ringing. A mythological based on Chhath Puja, one the important festivals of Bihar, was bound to be a hit. By way of illustration, he also spoke of the pull of certain emotionally charged words in the Bhojpuri psyche: the word Ganga (the name for the river Ganges) for example, occurred repeatedly in the songs and titles of Bhojpuri films ${ }^{5}$, such was the hold the 'sacred' river had on the psyche of the people. But he added that the odds were heavily loaded against a woman-oriented film or a mythological, whereas masala (spicy) entertainment was sure to reap rich returns from the box office. When huge amounts of money rode on each production, the safety of a sure-fire winner always won over the unpredictability of a message based film.

\section{The Way Things Worked...}

In Bhojpuri films it was fairly common to find 'one time producers'. A politician's son, or even the head of a corporate house, would harbour dreams of becoming an actor, director or producer. Since the glitzy, insular world of Bollywood (Hindi cinema) would probably be beyond his reach, 'Bhojwood' would be the next best option. Enamoured of the world of cinema, he would amass a sum of rupees 2.5 to 3 million and turn into a producer- financier. Thus new producers emerged, lured by the promise of quick gains held out by directors. Personal connections ruled the roost; bhai-bhatijawad, namely, nepotism, had precipitated the decline by facilitating the entry of greenhorns 'out to make a fast buck'. There was a further lowering of standards because the audiences were undiscerning and unquestioningly accepted the fare that was churned out. Fernandes observed that unless the producer was also the 
distributor, he was bound to sink. A distributor would buy a film for rupees 2 million, spend another rupees 500,000 on publicity, and hope to get rupees 3 million. His recovery expectations were not very high, because the very next week another film would be knocking at his door. "Jab har hafte do teen releases hain, toh pandrah hafte ek film ko khinchne mein kise interest hai?" he asked. (When there are more than two releases every week, why would anyone be interested in stretching a film's run to fifteen weeks?)

He offered an explanation as to why there was a sudden spurt in the growth of almost all regional cinemas. Multiplexes had come up about 7-8years back. The large, single screen theatres were often poorly maintained and seldom drew well-heeled patrons. Multiplexes changed the movie viewing experience, transforming it to resemble a complete outing for the family. Directors may have contemplated making socially sensitive films; but the popcorn eating, coke guzzling audience could scarcely be 'awakened' socially while in this frame of mind. Moreover, around this time, the number of Non Resident Indian viewers grew phenomenally, so the fresh crop of films assiduously sought to woo this segment. This was when the lower stall audiences, needed entertaining films that would draw them back to the single screen theatres. The demand was met by a spate of mainstream Hindi films like Dabang (2010), Singham (2011) and Bodyguard (2012) that raked in huge profits at the box office by poaching in the territory of regional cinema. The story line, the characterization, the songs and dance sequences were unapologetically borrowed from the formula of popular regional language films: the hero was a larger-than-life savior of the oppressed; the action was death defying; the music appealingly folksy and foot tapping; the heroine, decorative, but a two dimensional character. Reverse borrowings were witnessed: Bollywood trespassed into Bhojwood and the cinemas of the south, audaciously appropriating its distinctive features, 
repackaging them with the technical expertise brought in by big budgets and adding the irresistible attraction of mega stars like Salman Khan, Ajay Devgan and Kareena Kapoor.

\section{Nostalgia and Airbrushed Memories}

The research participants bemoaned that scarcely anyone in the Bhojpuri film industry was concerned with upholding Bhojpuri culture. In the process of churning out a carefully collected assemblage of commercial features, the depiction of regional ethos was an add-on that went on to enhance the flavor of the mélange and ensured box office success. The sole motive for including regional settings, selecting locations in UP and Bihar (apart from budgetary considerations), and spicing up the cinematic offering with generous doses of traditional fare, was to cash in on the nostalgia of the migrants.

No sentimental desire to help north Indians remain tethered to regional moorings propelled the producers. Both Chapekar and Khatri believed that the migrants' sentimental yearning for home and the emerging trends of identity politics were milked dry by the film makers, because that was what ensured success. Bucking the trend would involve risks that the financiers were loath to take; so whatever was successful at the marquee triggered off a trend. Several films of the same type were turned out, till the formula exhausted its potential to entertain and capture audiences.

Khatri narrated an interesting incident that took place in Mumbai after the premiere of his film Kab Hoi Gawana Hamar, one of the first Bhojpuri films to be shot extensively in Mauritius. Emerging from the theatre, an old man who had attended the premiere asked him, "Apni mitti ki khusboo nahi laaye?" (Could you not bring in the fragrance of our land?). Why 
had they not shown scenes from Bihar, was his query. While he appreciated the exotic locations in Mauritius that formed the backdrop of the film, he still longed to see his 'homeland', the state of Bihar with its villages, its cities, anything that would be redolent with the flavors and aromas of the state he had left behind.

Fernandes made an extremely crucial observation that, 'the village' as the film audiences understood it, existed only in the collective imaginary. It was a curious, but telling incident that he recounted. He was shooting for the film Aaj Ke Karan Arjun (2010) at a location close to Lucknow, in UP. His son, who happened to be the child star in the film, was made to wear a dhoti kurta (a loose shirt and an unstitched piece of cloth that forms the lower garment) to ensure fidelity to the milieu being depicted. A large crowd had gathered to view the shooting. Not a single boy in the crowd was wearing a kurta or a dhoti. The spectators did not sport gamchhas (towel like multi-purpose checked cloth that is the trademark of the north Indian rustic); they had mufflers around their necks and were attired in trousers, shirts and leather jackets. Where indeed were the oxen supposedly found tied to the post in the courtyard of every village home in UP and Bihar? Instead, there were tractors parked outside village dwellings. Where was the smoke that curled upwards from the little huts on winter morning? Fernandes asserted, “Gaon, Gaon Nahin raha... culture, culture bolte hain ...kahan hai culture? Woh culture sirf filmon mein reh gaya hai!" (Villages are no longer like villages... they keep talking about culture... where is the culture? It has remained alive only in the films).

Waldron ${ }^{6}$ had pointed out that preserving a culture often entails taking a 'snapshot' version of it and holding on to it "in its defined purity, irrespective of the surrounding social, economic and political circumstances". Perhaps the pull of the village was a strong force 
because most of the people who speak Bhojpuri language were predominantly from an agrarian background. In order to ensure authenticity, filmmakers 'organized' the milieu to suit their purpose. So the rangoli (the intricate designs drawn with powdered rice and coloured chalk) at the door, the celebration of festivals, the marriage rituals... were given generous coverage. If the trappings of modern technology were portrayed to the exclusion of the markers of identity, the complaint was loud and clear, "Aapne toh shaher dikha diya" (you have shown us the city). Ironically, none wanted to 'live' the way villagers once did; but all wished to see it in films. They had mobile phones; their children went to English schools; they sang Hindi songs and knew nothing of folk music. This peculiar paradox was also a reflection of a society caught in a flux between tradition (at least, its notion of tradition), and modernity as embodied in the 'English speaking metropolitan culture' of urban India.

\section{Target Audience: Different Sensibilities}

Chapekar drew attention to the differences in the aesthetic sensibilities of the migrants and the urban audiences in the metros: he spoke of the song and dance sequences in the nautanki performances and their transmutation into the item numbers of Bhojpuri cinema and video CDs. The difference, he claimed, was that between Mastram (a series of 'lowbrow' pornographic books popular in north India amongst the semi-literate), and the technically slick blue films churned out abroad: the purpose was to titillate; the viewership was male; the imagery and the lyrics were risqué; but the nautanki dances were to item numbers what Mastram books were to blue films. They represented the gradual transformation of the basic content into a glitzier, overtly seductive version of the original. Cinematic technique and technological advancement had turned rustic recreation into mass scale production of male 
fantasies. In the process, visual stimulation had been enhanced manifold, while the rustic roots had been retained through mere tokenism, cosmetic touches and superficial add-ons in the lyrics. Chapekar too pointed out that, "Bhiwandi ki galiyon mein Mercedes gadi theek nahi lagti" (A swanky Mercedes would be out of place in Bhiwandi). ${ }^{7}$ The producers of Bhojpuri films had to 'speak' the language of the viewers and address the needs of their patrons who wished to be seen as those who had 'arrived' on the socio cultural scene after shedding their bhaiya tag, a label synonymous with those who are uncouth and uncomfortable with the English language. The outcome was a pastiche, a hodge-podge of ingredients like the uniquely Mumbaiya Chinese bhel $^{8}$ the rustic and the urban, and even the global tossed in together, a crunchy, sweet sour, salty mix that represented the 'complicated' identity of the migrants in Mumbai; it also reflected the 'aspirations' of 'wannabe' Mumbaikars (residents of Mumbai), chafing against their bit in the small towns and villages of north India, waiting to arrive in the big city to fulfill their dreams, but defiantly holding on to their cultural values.

Significantly, Chapekar said, "Bihar ka cultural ego bahut bada hai" (Bihar has a huge cultural ego), therefore Biharis are unwilling to let go even of things that had outlived their usefulness. Elaborating on the subject, he offered the illustration of the devar-bhabhi (younger brother-in-law and sister-in-law) relationship, a friendship between affinal relatives of the same age, characterized by light hearted raillery and bantering. The theme was common in the folk literature of north and central India. Its rather bawdy representation in cinema and music videos however, was a cause for embarrassment among the elite of the region. It was the remnant of a culture that they sought to sanitize and re-package in the more acceptable gilt wrapping of respectability. Khaderia was more critical of the debasement of folk themes in the current crop of films. He believed it was a misconception that the overt vulgarity of the lyrics was a 
reflection of the risqué lyrics of folksongs, "Even Rajasthani folk songs (he himself is from the state of Rajasthan), have double meanings, but they are well balanced (sic). The bhabhi may be teased by her devar, but she is respected; Chanchalta hai, (there is mischief), but they don't cross limits. Today, they almost make it appear as if the two are sleeping together". He pointed out that if you 'allowed' such things, the floodgates would open, and vulgarity would swamp the media. Interestingly, Ravi Kishen had candidly admitted that the films catered to the repressed sexuality of migrant youth who were compelled to leave their spouses back in the villages. Yet Khaderia was skeptical of the view that the preponderance of sleaze owed much to the supposed 'sexual deprivation' among migrants. He asserted that only $20 \%$ of the market for Bhojpuri cinema is outside of Uttar Pradesh and Bihar; the films did as well in UP and Bihar, as they did elsewhere, an indication that what was on offer was in keeping with the tastes of the working class north Indian audiences.

Khaderia was aware that the educated upper classes amongst the migrants considered it ignominious to be associated with the Bhojpuri media. He spoke of the large number of top police personnel and IAS officers from UP and Bihar who resided in Mumbai. "They account for almost $30 \%$ of the total number of bureaucrats in the state," he asserted, "... they are ruling the state (sic)". This segment of the migrant population was embarrassed to declare its affiliations with Bhojpuri, a dialect associated with "people who are doing small jobs (sic)", he stated. The association of Hindi with refinement, social mobility and sophistication was not new. Even in Mauritius, where large swathes of the population of migrants spoke a variant of Bhojpuri, concerted efforts were being made by Hindu revivalist groups to portray Bhojpuri as 
the coarse dialect that was the offspring of Hindi, the Sanskritized mother. In India this division between highbrow culture and the lowbrow dialects had persisted and even been encouraged.

During the course of my study, many among my research participants demonstrated what adman Agnello Dias, Chairman and co-founder of Taproot India, an advertising agency, calls 'Collective Individualism'... the 'counter-intuitive space' from which most Popular Culture stems. He says, this is in evidence 'where an entire group of people feels that they are individually standing out because of something that appeals to them which is not the norm' ${ }^{9}$ This 'Collective Individualism' took the form of an aggressive espousal of Bhojpuri cultural texts. Surprisingly, this form of inverted snobbery was seen not just in the semi-literate men, but most often in the educated young male viewers who celebrated the kitsch and the bawdiness as cultural markers that were refreshingly lacking in hypocrisy. Their belligerent advocacy of Bhojpuri cultural artefacts appeared to be a reaction to the shame and distaste expressed by the champions of highbrow culture.

\section{Many Regional Cinemas: One Sensibility}

Notably, the boundaries between the various regional language cinemas were increasingly becoming fluid. A curious fact was that many Bhojpuri films these days were made with the help of film crew from the south Indian state of Andhra Pradesh. Sometimes only the lead artistes were from the Bhojpuri industry; at other times a film was made for two markets simultaneously and dubbed in Bhojpuri as well as Telugu. Perhaps what was significant was the similarity in tastes of the audiences for all regional cinemas across India. Whether it was Tamil, Telugu, Kannada or Bhojpuri, the English speaking 'metro' audiences had distinctly different expectations from their multiplex experiences, as compared to the lower 
middle class consumers of regional cinema. Pencil slim, size zero heroines were best suited to those with more 'global' exposure; desi (native) audiences preferred the likes of Rambha (a curvaceous South Indian beauty who is equally popular in Bhojpuri films e.g. Banke Bihari MLA-2007; Ram Balram-2007).

\section{Signs of Change}

Notwithstanding the migrants' fondness for entertainment rooted in familiar customs and conventions, signs of transformation were evident in Bhojpuri cinema. The research participants rued that not all of the new trends were healthy. For instance, jettisoning the regional flavor which was the unique selling proposition of Bhojwood, directors were bending over backwards to entice metro audiences by generously incorporating the stock features of popular Bollywood hits. Possibly, the attempt was to win back youth who were turning away from Bhojpuri films to the technically slicker Bollywood productions. The amalgam would probably work: dishing out a mix of Bollywood tricks with a generous seasoning of Bhojwood features would please for a while. After all, the 'urban' touches would be aspirational for the young people from UP, Bihar, within or without these states. Television programs had already experimented with such forms of fusion in reality shows and contests. But industry experts such as Khaderia were doubtful of the sustaining power of such cloning experiments. Ravi Kishen may have ardent fans in Bihar bathing his idol in milk, ${ }^{10}$ but the children of the migrants in Mumbai preferred the glamorous Bollywood superstars to Bhojwood's 'wannabe' heroes. 
On the contrary, when Bhojpuri films eschewed imitation and were faithful to their own ethos, when they depicted the social realities of the region artistically, they stood a greater chance of success at the box office. Khaderia cited the example of Ranbhoomi (Battleground) a film made in 2010 by Anil Ajitabh. The film, dealing with the Maoist insurgency in parts of Bihar, was commercially packaged, but made telling points. It had a fairly successful run at the box office too. The influence of his mentor Prakash Jha (known for films on socio-political issues) was evident in Ajitabh's directorial touches. Yet another example of a healthy trend was of the film Yadav Paan Bhandar (2011) which dealt with the travails of a north Indian migrant who set up a paan (betel leaf) shop in Mumbai.

\section{The Regional Connect}

Significantly, issues of identity politics always ensured success at the marquee. Fernandes claimed that his 2009 film Bhumiputra (Son of the Soil) had been 'conceptualized' on the basis of newspaper reports about the 'anti north Indian' agitations unleashed by the Maharashtra Navnirman Sena, a regional political party. The film, which made a strong plea statement against regionalism, opened to packed houses in Bihar, but was not released in Mumbai, possibly owing to the fear of a backlash from the host population.

Overemphasis on regional identity may have been reviled in Bhumiputra, but the success of 'Metro Mumbai', a local Bhojpuri cable channel operating in the northern suburbs of Mumbai, owes much to the migrants' resurgent pride in the north Indian ethos. Inderpal Chaturvedi, erstwhile crime reporter with the tabloid Dopahar Ka Saamna (The Afternoon Confrontation), had launched the channel with a crew of just nine. He ensured that the local population was given regular news updates. His reporters, sent to different parts of Mumbai to 
get sound bites, also doubled up as news readers, a fact that is testimony to his judicious use of resources. He was aware that the bigger operators and the national level Bhojpuri channels like Mahuaa TV had an edge over his fledgling efforts; however he had the advantage of having his ear to the ground as far as local news was concerned. Moreover, his TV channel held music and dance contests for the young people of the locality, providing them with a platform to showcase their talents and gain instant celebrity status in the area. His viewers repeatedly requested that music albums be screened on 'Metro Mumbai'. Hence, in association with Amardeep Entertainment Private Ltd., a small time media company, Chaturvedi also shot music videos using local talent, at a cost of about rupees 25,000 to 30,000 each, ${ }^{11}$ besides, he also captured on film the occasional variety entertainment programs of Bhojpuri music and dance held in the suburbs of Mumbai. He acknowledged the need for 'clean' entertainment that appealed to the refined tastes of the educated class among the migrants and professed concern about the degradation of Bhojpuri culture which was being increasingly contaminated with asabhyata (vulgarity). Therefore the need for course correction; and therein lay his channel's contribution. By screening music albums on religious and devotional themes, and music videos that are 'sober', he sought to uphold a culture that was essentially pristine.

\section{'Bhojpuri City': Setting the Direction}

Chaturvedi's denouncement of grossness in Bhojpuri media resonated with the educated elite among the migrants. Bhojpuri City, the film trade magazine Khaderia published, revealed all the contradictions inherent in the relationship between the producers, the consumers (audiences) and the media texts. In the September 2011 issue, Editor Akhilesh Kumar's editorial set the tone by calling upon those associated with the Bhojpuri media to introspect. $\mathrm{He}$ 
deplored the fact that Bhojpuri films were a mélange of elements drawn from Hindi films and had forsaken all that was quintessentially north Indian. He maintained that the attempt to compete with Hindi films was self-defeating, for the budgetary constraints did not allow Bhojpuri film makers to emulate or even approximate the glamour of the big budget Hindi cinema. He wrote: 'Bhojpuri filmon ki disha kya ho? Aaj aisi filmein banayi jaayen jinmein Bhojpuri mass appeal ho... Bhojpuri bhasha, sanskriti, reeti-rivazon ko aadhar banakar filmein banana hongi... Aaj Bhojpuri cinema se mahilayen doori bana kar rakhti hain. Unhe Bhojpuri cinema phuhad lagta hai' (What should be the direction in which Bhojpuri cinema should move? The kind of films that should be made today must have mass appeal. At present, women maintain a distance from Bhojpuri films. They find Bhojpuri cinema gross).Further, Akhilesh Kumar made a plea for films that were replete with the flavor of the region (aanchalikta); the kind in which the plot, the traditions, the values and the music were distinctively Bhojpuri. Only then could the industry carve a niche for itself and make its mark.

The pragmatism underlying these lines was evident. Bhojpuri cinema, in an attempt to compete with Bollywood, was borrowing every saleable trick used by Hindi films; the expectation was that by providing all that Bollywood does, but ensuring that the language was the reassuringly familiar, it could give its patrons 'the newest wine in the old bottle'. This reduced Bhojpuri cinema to the status of a climber, an arriviste. But this also guaranteed it success among the quasi literate male patrons whose aspirations were projected on the celluloid screen by the larger than life 'modern' heroes; who vicariously experienced the fulfillment of their romantic dreams through the capers of heroes such as Dinesh Yadav, Khesarilal, Manoj Tiwari and Ravi Kishen. On the other hand, the desire for antiseptic, clean family films made 
business sense: women, who shied away from the vulgarity of Bhojpuri cinema, could then be lured back to the theatres.

Khaderia's own write up in the issue of Bhojpuri City threw interesting light on an issue: he was all praise for the reality show Naach Nachaiya Dhoom Machaiya on Mahuaa channel. He pointed out that the participation of popular female actors like Rinku Ghosh and Gunjan Pant had paved the way for the entry of these women into the 'drawing rooms' of homes. He admitted, "In abhinetriyon ke darshak kaamatur par purush hi hote hain"... (the audience for these heroines' films is comprised chiefly of lascivious men). He was hopeful that women would also become a part of the audiences for Bhojpuri films after watching these actors on television, within the confines of the living room. Incidentally, heroines from states other than UP and Bihar had been ruling the roost in Bhojpuri cinema. ${ }^{12}$ The writer was of the opinion that girls from these states were trammelled by the feudal mindset of a society that viewed singing and dancing in public as the domain of courtesans and nautch girls. Besides, burdened by inhibitions, even those Bhojpuri speaking girls who ventured to act in films were unable to essay 'bold' roles that actors from other parts of India had no reservations in taking up. The very same men who were ardent fans of Bollywood heroines assiduously kept their daughters away from the film industry. Matters were unlikely to change as long as such double standards prevailed.

Notwithstanding Akhilesh Kumar's contention that coarseness was the bane of Bhojpuri media, every page of this film trade magazine had pictures of starlets in the skimpiest of clothes. The producers might fulminate and pontificate from their elevated positions as the educated elite, but in the end, they acknowledged that 'mass appeal' did not lie in the formula of Parivarik film 
mein samajik sandesh, (family dramas with a social message); success was guaranteed when a popular new actor like Viraj Bhatt performed death defying action stunts, a heroine like Pakhi Hegde sported a 'hot look' and item girl Sambhavna Seth performed a 'dance blast'. Abandoning these saleable features would be a risk; while retaining the risqué elements would seriously hamstring their attempt to widen their audience base.

\section{Bhojpuri and Hindi: Borrowing and Bickering}

Bhojpuri media are at the crossroads, as is the language: on the occasion of Hindi Diwas (Hindi Day), which falls on the $14^{\text {th }}$ of September, Bhojpuri City featured an article by Dhirendra Kumar Tiwari. The article, written in the form of an autobiography, highlighted the contributions of great poets and writers like Kabir and Bhikhari Thakur who had enabled the Bhojpuri dialect to attain a position of eminence. But the lines that stood out were, 'Main hoon Bhojpuri. Hindi ki sabse dulari, pyari or nyari beti' (I am Bhojpuri... the most beloved, lovable and unique among the daughters of Hindi). The writer made a fervent appeal to the sapoot (good, dutiful sons) of Bhojpuri to cleanse Bhojpuri cinema of its ashlilta aur phuhadpan (obscenity and coarseness). He also made a plea for the status of a national language for the dialect, and standardization of the many forms of Bhojpuri. Hindi is regarded as the refined, pristine 'mother' whose progeny included dialects such as Maithili, Brajbhasha and Magahi. Today Bhojpuri media are reeling under a threat from this very 'mother'. This is a problem peculiar to north Indian dialects; the audiences for Telugu or Tamil cinema remained more or less loyal to their regional films. Conversely, the audiences for Bhojpuri films veered towards Hindi, not only because Hindi was understood by all of them, but also because Hindi media products were infinitely more glitzy and therefore, had up-market associations. An article in

CINEJ Cinema Journal: Sleaze, Slur... and the search for a sanitized identity: Bhojpuri media at crossroads

Volume 5.1 (2015) | ISSN 2158-8724 (online) ｜ DOI 10.5195/cinej.2015.130 | http://cinej.pitt.edu 
Bhojpuri City ${ }^{13}$ (written in the Bhojpuri dialect but in Devnagari i.e. the script used for Hindi) highlighted the many occasions when Hindi filmmakers had introduced Bhojpuri songs into their films, and how these songs had gone on to become all-time favourites. Some of the popular ones were from the films Nadiya ke Paar (1982), Godaan (1963), Teesri Kasam (1966) and Don (1978). Notably, cinematic representations of the Bhojpuri speaking country bumpkin whose native intelligence sees him through various ordeals had been the protagonist of hugely successful Bollywood comedies: for example, Govinda in Dulhe Raja (1998) and Madhavan (a Tamilian actor) in Ramji Londonwaley (2005). In short, the close bonds with Hindi, the borrowings from Bollywood and the fear of subsumption by the all-powerful Hindi media... these were omnipresent in the minds of Bhojpuri media producers. This was the biggest threat Bhojpuri cinema, and by extension, the Bhojpuriya identity faced: erasure and subsequent extinction owing to the dominance of Hindi; particularly because Hindi media seduce the migrant community with the hope of instant social mobility. So it was not just the migrant whose identity was threatened by the overpowering cosmopolitanism of the host city, Bhojpuri media too were experiencing an identity crisis: whether to emulate the richer, sophisticated cousin (Hindi media), or to cling even more tightly to a cultural identity that had its roots in rural society and folk traditions.

\section{Fashioning New Identities}

In Desperately Seeking the Audience, Ien $\mathrm{Ang}^{14}$ states that there is no mechanism that can assess the complex practices and experiences of 'audiencehood'. My encounters with producers of media artefacts underscored the fact that they considered the audience's predilections and preferences incalculable and mysterious. However, they seemed to have a 
fairly accurate idea of what are the 'needs' of their patrons; possibly because those involved in the production of these media offerings were drawn from the same sections of society that the audiences belonged to. Chaturvedi and Ghatraj were not too far removed in terms of socio economic background from the people they sought to entertain. No esoteric artistic vision blinded them to the migrants' realities.

In mass media culture audiences are positioned and constructed by the structures of cinematic and TV representations ${ }^{15}$. People are repeatedly 'interpellated', i.e. they are addressed as people with a certain set of values and desires, as ones who value certain qualities, till they actually 'internalize' media messages subliminally and behave in the manner described. According to the observations of my research participants, there was no agenda setting on the part of the producers of media messages. The industry was market driven, and that which held perennial appeal was always included. However, despite assertions to the contrary, in the final analysis the audience was interpellated in a way so as to be constructed as a member of the 'Bhojpuri' community. The media drew upon the community's notions of its own distinctive identity; and the screen representations only served to reinforce these notions. ${ }^{16}$ Upholding the 'Bhojpuriya' culture was never on the agenda of the producers; however, nostalgia, as embodied by the term Mitti ki Khushboo (the smell of the soil), was the single most important element that guaranteed success in the market. Besides, the massive 'cultural ego' Chapekar spoke of was bolstered by glorifying aspects of the north Indian ethos, and evolving in tune with the audience's aspirations. For instance, while reality shows on the Bhojpuri television channels such as Mahuaa replicated the format of dance contests on Hindi channels, anchors and judges such as Ravi Kishen and Sudha Chandran sang praises of the 'Bhojpuriya' culture, ensuring that the language and the content were pegged at the level their 
viewers were most comfortable with. New identities were being formed through cinema and televisual representations: an idyllic, dream of 'gaon' (village); an upper class sanitized version of Bhojpuri media culture divested of its embarrassing explicitness; an urbane hero and his fashionable girlfriend who were 'Bhojpuriyas' at heart. The Bhojpuri media therefore were positioning their subjects so as to reflect what was of significance to them. In fact, it was difficult to gauge where the influence of the media ended and to what extent the audience's unmet needs governed media production choices. Even as the producers derived matter for cinematic and televisual narratives from the milieu in which they operated, they generated, constructed and consolidated identities.

\section{BIBLIOGRAPHY}

Althusser, L. "Ideology and Ideological State Apparatuses". In: Lenin and Philosophy, and Other Essays, trans. Ben Brewster (London: New Left Books, 1971) Available at: www.rlwclarke.net/.../LITS3304/.../07Althusser.

Ang, I. Desperately Seeking the Audience. (London and New York: Routledge, 1991)

Bagchi, S., and Ganesan, Ram S. "Hot South is Cool.” Times Crest, January28, 2012, 20

Bha, A. "Hero Yahanke, Heroine Wahan ki”, Bhojpuri City. Oct-Nov, 2011, 43-44.

Creswell, J. W. Research Design: Qualitative, Quantitative and Mixed Methods Approaches. $2^{\text {nd }}$ ed. (Thousand Oaks, CA: Sage, 2003) 
Ghosh, A. Cinema Bhojpuri (New Delhi: Penguin, 2010)

“Hindi Filmonmein Bhojpuri Geet.”. Bhojpuri City. October. 2011, 56-57.

Kellner, D. Cultural Studies, Multiculturalism, and Media Culture (1994) Available at: http://pages.gseis.ucla.edu/faculty/kellener/papers/SAGEcs.htm

Lincoln, Y. S. and Guba, E. G. "Paradigmatic Corntroversies, Contradictions, and Emerging Confluences". In Handbook of Qualitative Research, eds N. K. Denzin, Y. S. Lincoln, and E. G. Guba. $2^{\text {nd }}$ ed. (Thousand Oaks, CA: Sage, 2000) 163-188

Salambhojpuria. Ravi Kissen Fans Pour Milk on his cut outs. September 19, 2011. Available at: http://youtu.be/54tdXBMLiVE.

Schwandt, T. A.“Three Epistemological Stances for Qualitative Inquiry: Interpretivism, Hermenutics, and Social Construction". In Handbook of Qualitative Research, eds. N. K. Denzin and Y. S. Lincoln, (Thousand Oaks, CA: Sage, 2000) 189-213

Sinha, A. Bhojpuri City. September, 2011, 39.

Waldron, J. "Minority Cultures and the Cosmopolitan Alternative". In The Rights of Minority Cultures, ed. Will Kymlicka (Oxford: Oxford University Press, 1995) 


\section{Endnotes}

${ }^{1}$ Lincoln, Y. S. and Guba, E. G. "Paradigmatic Controversies, Contradictions, and Emerging Confluences". In Handbook of Qualitative Research, eds. N. K. Denzin, Y. S. Lincoln, and E. G. Guba. $2^{\text {nd }}$ ed. (Thousand Oaks, CA: Sage, 2000) 163-188

Schwandt, T. A. "Three Epistemological Stances for Qualitative Inquiry: Interpretivism, Hermenutics, and Social Construction". In: Handbook of Qualitative Research, eds.N. K. Denzin and Y. S. Lincoln (Thousand Oaks, CA: Sage, 2000) 189-213

${ }^{2}$ Creswell, J. W. Research Design: Qualitative, Quantitative and Mixed Methods Approaches. $2^{\text {nd }}$ ed. (Thousand Oaks, CA: Sage, 2003)

${ }^{3}$ Kellner, D. 1994. Cultural Studies, Multiculturalism, and Media Culture. Available at: http://pages.gseis.ucla.edu/faculty/kellener/papers/SAGEcs.htm.

${ }^{4}$ Nautanki is a form of folk theatre popular in the north Indian states of Uttar Pradesh and Bihar. It is also a term used in common parlance to denote exaggerated, melodramatic acting.

${ }^{5}$ Ghosh, A. Cinema Bhojpuri. (New Delhi: Penguin, 2010)

${ }^{6}$ Waldron, J. "Minority Cultures and the Cosmopolitan Alternative". In The Rights of Minority Cultures, ed. Will Kymlicka. (Oxford: Oxford University Press,1995)

${ }^{7}$ Bhiwandi, a city in Thane district, is part of the Greater Mumbai metropolitan agglomeration. It has the largest number of power looms in India; and the highest number of migrants in the state of Maharashtra, mainly from Bihar, eastern UP and West Bengal.

${ }^{8}$ A popular roadside snack that mixes crisp noodles with typically Indian ingredients.

${ }^{9}$ Bagchi, S., and Ganesan, Ram S. "Hot South is Cool." Times Crest, January28, 2012, 20.

${ }^{10}$ Salambhojpuria. Ravi Kissen Fans Pour Milk on his cut outs. September 19, 2011. Available at: http://youtu.be/54tdXBMLiVE.(Members of the Ravi Kishen fan club from Patna, Mujaffarpur, Motihari and Katihar congregated at the Veena Cinema Hall in Patna, poured milk on his cut-outs and prayed for the actor's deliverance from the problems arising out of his maid's suicide)

${ }^{11}$ Chaturvedi screened one of the music videos for me in his little two-room office-cum-studio in Thakur Village, Kandivali east. The video featured Chaturvedi himself, lip syncing to a Bhojpuri folk song about the sylvan beauty of the landscape.

12 Bha, A. "Hero Yahanke, Heroine Wahanki", Bhojpuri City. Oct-Nov, 2011, 43-44.

13 "Hindi Filmon mein Bhojpuri Geet", Bhojpuri City. October. 2011, 56-57.

(Bhojpuri City acknowledges that the article has been sourced from Bhojpuri Mati, a monthly magazine published by the Pashchimbanga i.e., West Bengal Bhojpuri Parishad. The author chooses to remain anonymous)

${ }^{14}$ Ang, I. Desperately Seeking the Audience. (London and New York: Routledge,1991)

15 Althusser, L. "Ideology and Ideological State Apparatuses". In Lenin and Philosophy, and Other Essays, trans. Ben Brewster (London: New Left Books, 1971) Available at: www.rlwclarke.net/.../LITS3304/.../07Althusser.

${ }^{16}$ Ravi Kishen noted that the overriding concern with identity and the eagerness to anchor themselves to their roots was in evidence even amongst the Bhojpuri speaking migrants in Fiji and Mauritius. Their forefathers had been taken to British and European colonies as indentured labour. 